\title{
A PARTE GERAL dO ANTEPROJETO DE CÓDIGO CIVIL BRASLLEIRO
}

JOSÉ LAMARTINE CORRÊA DE OLIVEIRA

fessor de Direito Civil nas Universidades Federal

e Católica do Paraná).

\section{SUMÁRIO}

1. Limitações e características do trabalho

2. Características Genéricas do Anteprojeto

3. Das pessoas físicas

3.1. O problema terminológico

3.2. Personalidade e capacidade de direito

3.3. Incapacidade de fato

3.3.1. Incapacidades derivadas da idade

3.3.2. Outras causas de incapacidade

3.3.2.1. A doença mental

a) $O$ sistema vigente

b) O sistema proposto

c) Cotejo

d) O Direito Comparado

e) Conclusão crítica

3.3.2.2. Surdo-mudez e outras causas.
a) O sistema vigente
b) O sistema proposto
c) Direito Comparado
d) Conclusão crítica

3.3.3. Incapacidade acidental

3.3.4. A ausência

3.4. Dos direitos da personalidade

3.4.1. Breve noção

3.4.2. Omissão

3.4.3. Crítica 
4. Das pessoas jurídicas

4.1. Das pessoas jurídicas de Direito Público Interno

4.2. Das pessoas jurídicas de Direito Privado

4.3. Das sociedades irregulares

4.4. O combate ao abuso

4.5. Os direitos de personalidade

5. Os bens

5.1. Das diferentes classes de bens

5.2. O Bem de Família

6. Dos Fatos Jurídicos

6.1. Da classificação

6.2. Generalidades

6.3. Condição, termo e encargo

6.4. Dos defeitos do negócio jurídico

6.4.1. Do erro

6.4.1.1. Delimitação do erro substancial - o problema da cognoscibilidade

6.4.1.2. O erro de Direito

6.4.1.3. Erro quanto ao motivo

6.4.2. Do dolo

6.4.3. Da coação

6.4.3.1. Pressupostos

6.4.3.2. Da coação exercida por terceiro

6.4.4. Da simulação

6.4.5. Da fraude contra credores

6.4.6. Da lesão e do estado de perigo

6.4.6.1. Da lesão

a) Os antecedentes de Direito Comparado

b) Anteprojeto

6.4.6.2. Do estado de perigo

6.4.7. Omissões

6.5. Sistema de nu!idades

6.5.1. Casos de nulidade absoluta

6.5.2. Conversão do nulo

6.5.3. Casos de anulabilidade

6.6. Prescrição e Decadência

6.7. Da prova 
Comunicação apresentada ao Instituto dos Advogados do Paraná por seu então Presidente Prof. José Lamartine Corrêa de Oliveira, sobre: LEIRO".

"A PARTE GERAL DO ANTEPROJETO DE CÓDIGO CIVIL BRASI-

1. Limitações e características do trabalho. Dada a urgência da remessa, em tempo útil, à Comissão Elaboradora e Revisora, da contribuição das entidades profissionais, e dos especialistas em Direito Civil, e dada a exiguidade desse tempo útil, fixado com critério avaro, o presente trabalho não terá pretensões a erudição. Breviłatis causa, foram minimizadas as invocações doutrinárias. Eis que o assunto ainda não é de suficiente domínio público, a presente comunicação reveste-se de características a um tempo informativas e críticas, procurando-se, de modo concomitante, informar as principais alterações projetadas relaitivamente ao Direito vigente e formular sobre tais alterações juízos valorativos.

2. Características genéricas do Anteprojeto. Fruto do trabalho de uma Comissão, ressente-se o Anteprojeto do defeito das repetições e das incoerências, tão encontradiço em trabalhos de equipe. Não conseguiu a revisão geral, entregue à inteligência privilegiada do Prof. MIGUEL REALE, suprimir de modo total tais defeitos. A responsabilidade setorial coube quanto à Parte Geral, ao prof. JOSÉ CARLOS MOREIRA ALVES, quanto ao Direito das Obrigações, ao prof. AGOSTINHO ALVIM; quanto ao Direito das Coisas, ao prof. EBERT CHAMOUN; quanto ao Direito de Família, ao prof. CLOVIS DO COUTO E SILVA; e quanto ao Direito das Sucessões, ao prof. TORQUATO CASTRO. (1)

No assunto que nos vai ocupar, fundamental a colaboração do eminente professor CLOVIS DO COUTO E SILVA, que, através de frutuoso debate com o prof. MOREIRA ALVES, de muito enriqueceu a elaboração da PARTE GERAL DO ANTEPROJETO.

Mereceu elogios a preservação da Parie Geral e a ordem dos livros da Parte Especial - Obrigações, Coisas, Família, Sucessões, a mesma do BGB, do Código helênico de 1941, do Código Português de 1966, superior, inclusive do ponto de vista didático - o que a tem feito prevalecer no ensino jurídico - à ordem adotada pelo Código vigente. A louvável preocupação de respeito ao essencial do trabalho de CLOVIS BEVILAQUA fez com que a estrutura básica do Código vigente fosse respeitada. $O$ exagero de tal preocupação pri-

(1) Além do trabalho do prof. SYLVIO MARCONDES, quanto à parte dencminada "Da Atividade Negocial". 
vou, porém, o Anteprojeto, de atualizações que se impunham, em determinados sefores. Duas observações preliminares, ainda. Declaradamente buscou o Anteprojeto antes "sentido operacional do que conceitual" (pág. 9 da Exposição de motivos) e uma superação do individualismo que se concretizou, a exemplo do Código luso, pela grande autoridade conferida ao prudente arbítrio do iuiz e pelo "apelo a valores como os de boa-fé, equidade, probidade, finalidade social do Direito, equivalência de prestações, etc." No fundo, portanto, em termos de pensamento inspirador, filia-se o Código à filosofia do Estado intervencionista, que procura, através do apelo ao ético, supostamente humanizar a estrutura econômica de raiz néo-capitalista. Confessamos nosso ceticismo quanto ao êxito dessas tentativas, embora esse ceticismo não se inspire nem no mecanicismo nem no naturalismo de antemão profligados na Exposição do prof. Reale. (pág. 13).

\section{Das pessoas físicas}

3.1.0 problema terminológico. Julgamos pouco feliz o abandono da expressão pessoas naturais adotada pelo Código vigente. Nossa posição deriva de uma tomada de posição filosófica. Entendido o homem como todo indissociável de matéria e espírito, não tem sentido denominá-lo pessoa física, como se a tangibilidade fosse sua propriedade fundamental. Ao contrário, a expressão pessoa natural encontra raiz filosófico-jurídica muito mais segura o homem, pessoa em virtude da própria natureza das coisas, pessoa como realidade substancial, enquanto que a pessoa jurídica é pessoa por analogia.

3.2. Personalidade e capacidade de direito. A melhor Doutrina não se limita hoje a estabelecer a tradicional distinção entre capacidade de direito, ou de gozo e capacidade de fato, ou de exercício. Indo mais além, recusa-se a sinonimizar personalidade, qualidade invariável, insuscetível de gradações e de limitações, e capacidade de direito ou de gozo, da qual a primeira é indispensável pressuposto, pois só a pessoa tem direitos, mas que pode sofrer limitações, restrições, ser maior ou menor. Pode uma pessoa, embora plenamente pessoa, pois não pode haver personalidade maior ou menor (raiando pela heresia aquilo que, em outras eras, chegou a figurar na linguagem jurídica francesa, a "petite personnalité") ter capacidade de direito diminuída, comparativamente à de outra pessoa. É o caso dos estrangeiros (que não podem adquirir direitos políticos e que, mesmo na esfera privada, não podem adquirir certos direitos - propriedades imobiliárias na faixa de fronteira, v.g.) como é, até certo ponto, o caso das sociedades irregulares, na vigência do art. $20 \S 2 .^{\circ}$, do Código Civil. 
Já há magníficos antecedentes legislativos para a distinção entre personalidade e capacidade de Direito. $O$ art. 11 do Código Civil suiço - "Toute personne jouit des droit civilis. En consequence, chacun, a dans les limites de la loi, une aptitude égale à dévenir sujet de droits et d'obligations". Melhor ainda, mais claro, mais explícito, o art. 67 do recente Código português. "As pessoas podem ser sujeitos de quaisquer relações jurídicas, salvo disposição legal em contrário: nisto consiste a sua capacidade jurídica". Não contém ○ Anteprojeto nenhum dispositivo que permita fundamentar a distinção, tão importante do ponto de vista científico. Tal é, a nosso ver, grave omissão.

\subsection{Incapacidade de fato}

3.3.1. Incapacidades derivadas da idade. Não se alterou, basicamente, o sistema de incapacidades de fato derivadas de idade, mantendo-se inclusive os limites etários, considerados absolutamente incapazes os menores de 16 anos e relativamente incapazes os maiores de 16 e menores de 21 anos (art. $4 .^{\circ}, 1 .^{\circ}$ e $5 .^{\circ}$ ), I). Não nos situamos entre os apologistas da redução de tais limires nem entre os partidários da fixação da marca dos 18 anos como genérica para a extinção de todas as restrições legais etárias. Aplaudimos, quanto ao ponto, o conservantismo da Comissão. Entre os 18 e os 21, o jovem ainda não dispõe, via-de-regra, dos requisitos mínimos de experiência e conhecimentos para a vida civil.

3.3.2. Outras causas de incapacidade. No que tange às outras causas de incapacidade, o sistema foi basicamente alterado. Por um lado, são absolułamete incapazes os que, por enfermidade mental, não tiverem o necessário discernimento para a prática desses atos" (art. $4 .^{\circ}$, II) e relativamente incapazes "os submetidos a curatela limitada, por fraqueza de espírito, embriaguez habiłual ou vício de tóxi$\cos ^{\prime \prime}$ (ari. 5. $\left.{ }^{\circ}, \mathrm{II}\right)$. Por outro lado são absolutamente incapazes "os que, por causa permanente, como a surdo-mudez, não puderem exprimir a sua vontade" (art. $4 .^{\circ}$, III), ao passo que se consideram relativamen. te incapazes "os surdo-mudos sujeitos a curatela limitada". Foi manti da a incapacidade relativa dos pródigos e silvícolas.

\subsubsection{A doença mental}

a) O sistema vigente. No Código vigente, os "loucos de todo - gênero" são absolutamente incapazes. Nulos os atos que praticarem por si, são, na vida civil, representados pelo curador. A eventual interdição do louco é, como a dos demais absolutamente incapazes, declaratória quanto à incapacidade, e apenas constitutiva quanto ao regime de curatela. A grande grita levantada quanto à discutida 
adequação de tal regime normativo aos postulados da ciência psiquiátrica terminou por fazer com que a legislação extravagante, em especial o decreto 24.559 e o decreto-lei 891, matizasse o quadro legal, em benefício da maior fidelidade à multiplicidade de casos apontados pela ciência (mas em prejuízo da nitidez e clareza geométricas). Permitiram tais diplomas a nomeação de administrador provisório de bens. Permitiram ainda que, na sentença de interdição, definisse o juiz a incapacidade do doente mental como absoluta ou relativa, o que equivaleu à criação de figura nova em nosso Direito - a do doente mental relativamente incapaz, inovação que, na prática, não foi bem acolhida pelo Judiciário, que preferiu coníinuar fiel à rigidez do Código, considerando-a preferível por motivos de segurança jurídica. A referida legislação extravagante previu também, de modo específico, a interdição dos toxicômanos, em dispositivos à parte, não os considerando, pois, de modo implícito, como loucos de todo o gênero.

b) O sistema proposio. No Anteprojeto há um caso de absoluta incapacidade, o caso das pessoas que, por "enfermidade mental", "não tiverem o necessário discernimento" para a prática dos atos da vida civil (ari. $4 .^{\circ}$, II) e um de relativa incapacidade, o dos submetidos a curatela limitada por fraqueza de espírito, embriaquez habitual, ou vício de tóxicos. Fica então clara a posição dos toximômanos e a dos ébrios contumazes que, em fim de contas, são toxicômanos de tipo especial. São relativamente incapazes sempre submetidos a curatela limitada. Fica também clara a situação dos doentes mentais - são absoluiamente incapazes. Cria-se, porém uma categoria nova, a das pessoas portadoras de "fraqueza de espírito", expressão infeliz à qual retornaremos.

c) Cotejo. Do que vem de ser dito, resulta que o panorama do nosso Direito aparentemente melhorará em clareza a segurança no que tange aos enfermos mentais (sempre absolutamente incapazes) e no que tange aos ébrios contumazes e toxicômanos (sempre relativamente incapazes). Mas - quem são as pessoas portadoras de "fraqueza de espírito"? São os neuróticos? Não é crível. Serão os oligofrênicos, portadores de deficit intelectual em vários graus? Se foi a eles que se quis referir o Anteprojeto, a expressão e imprecisa e anti-científica pois, em fim de contas, fraqueza de espírito nada é, em termos de ciência. Por outro lado, tem-se a impressão de que a locução empregada - fraqueza de espírito - é propositalmente imprecisa, de modo a abranger, inclusive, algumas categorias de psicóticos que seriam distinguidos dos absolutamente incapazes pelo instituto da curatela limitada. Haveria então psicóticos interditáveis por 
enfermidade mental (absolutamente incapazes, com eficácia declaratória da interdição) psicóticos interditáveis por fraqueza de espírito, com curatela limiłada (relativamente incapazes, com eficáca constitutiva da interdição).

d) O Direito comparado. O sistema é complicado e parece inspirar-se em precedentes estrangeiros. O do Código italiano, que prevê a interdição dos que si trovano in condizioni di abituale infermiłà di mente che li rende incapaci di provvedere ai propri interessi, art. 414, e a inabilitação menos grave que a interdição, dos doentes mentais quando seu esiado non é talmente grave dar far luogo all'interdizione, bem como dos que per prodigaliłà o per abuso abiłuale di bevande alcooliche o di stupefacenti, espongonose o la loro famiglia a gravi pregiudizi economici, art. 415 . O do Código helênico, cujo art. 1.686 prevê tułela e interdição para as pessoas portadoras de doença mental durável e que se encontram hors d'éłat de prendre soin de sa personne ou de son patrimoine, cujo art. 1.691 se contenta com um conseil judiciaire para as pessoas cuja doença mental não exclua inteiramenie o uso da razão ou de estado mental duvidoso. E o recente Código português, que prevê inṫerdição nos casos de anomalia psíquica, quando os doentes "se mostrem incapazes de governar suas pessoas e bens" (art. 138) e inabilitação para os os casos de habiłual prodigalidade, abuso de bebidas alcoólicas ou de estupefacientes quando os inabilitandos "se mostrem incapazes de reger convenientemente 0 seu patrimônio", (art. 152).

e) Conclusão crítica. A conclusão que se impõe é de fácil exîração - a Comissão decidiu acompanhar os precedentes dos Códigos que optaram pela criação de duas categorias de incapacidades por doença mental, rompendo, portanto, com o critério rígido, mas seguro, consagrado pelo art. $5 .^{\circ}, \mathrm{II}$, do Código atual. Já na opção foi, a nosso ver, infeliz a Comissão. É que os precedentes legislativos apontados fixam, para estabelecer a fronteira entre a doença mental que autoriza interdição e a que só aưoriza inabilitação, critério, no fundo, meramente quantitativo, dependente, sempre, do arbítrio judicial. Isso é particularmente claro no caso dos precedentes italianos e português, em que, a inabilitação se aplica aos doentes mentais quando seu estado psíquico não seja tão grave que justifique a interdição. Portanto, puramente quantitativa a fronteira entre os dois tipos de incapacidade. A fluidez de um tal critério desde logo já desaconselharia sua imiłação. A Comissão, porém, fez algo mais grave - não forneceu critério algum, limitando-se a distinguir entre os enfermos de mente que, quando não tenham o necessário discernimento para a prática dos atos da vida civil, são absolutamente incapazes, e os fracos de espírito quando submetidos a curatela limitada. Duas observações se 
impõem, de modo a evidenciar a fragilidade do sistema proposto. A contrário sensu, haverá doentes capazes, os que, embora doentes mentais, tenham o necessário discernimento para a prática dos atos da vida civil? (art. $4 .^{\circ}, \mathrm{II}$ ). Os inconvenientes práticos de uma tal interpretação, seus evidentes perigos como sementeira de chicanas, ressaltam aos olhos. Por outro lado, onde se encontra a distinção entre a curatela limiłada e a curałela, tout court, sem limites? Em nenhum lugar do Anteprojeto, nem na parte relativa às incapacidades, (Parte Geral nem na parte relativa à curatela, no Livro IV - Direito de Família. E extremamente grave criar-se um instituto sem que the apontem os contornos e os efeitos. A isso tudo se acrescentem as observações críticas já feitas no que concerne à ambiguidade da locução fraqueza de espírito (item 3.3.2.1.c)

\subsubsection{Surdo-mudez e outras causas}

a) O sistema vigente. Quanto aos surdo-mudos, são eles, pelo texto do Código atual, art'. 5. ${ }^{\circ}, \mathrm{III}$, absolutamente incapazes. Há, no Direito atual, surdo-mudos plenamente capazes, por saberem expressar sua vontade, surdo-mudos absolutamente e totalmente incapazes, surdo-mudos de incapacidade limitada (embora absoluta) na forma do art. 451 do Código Civil, ou seja - surdo-mudos plenamente capazes para alguns atos da vida civil e absolutamente incapazes para outros atos. Em relação aos atos para os quais exista incapacidade absoluta, são aplicáveis ao surdo-mudo todos os princípios vistos acima, isto é eficácia declaratória da interdição, representação pelo curador, nulidade de atos praticados sem representação. Não existe nenhum ato em relação ao qual seja incapacidade relativa do surdo-mudo.

b) O sistema proposto. Ora, o Anteprojeto altera de modo profundo tal regramento. Cria duas categorias de surdo-mudos: os absolutamente incapazes (art. $4 .^{\circ}, \mathrm{III}$ - "os que, por causa permanente, como a surdo-mudez, não puderem exprimir a sua vontade) e os relativamente incapazes (art. 5., III - "os surdo-mudos sujeitos a curatela limitada"). Pode portanto haver surdo-mudos absolutamente incapazes, e relativamente incapazes. Mas pode haver também outras causas permanentes geradoras de incapacidade absoluta, eis que a referência à surdo-mudez, no art. $4 .^{\circ}$, Ill (causa permanente, como a surdo-mudez) é meramente exemplificativa, enquanto que, no caso da incapacidade relativa, a referência à surdo-mudez é excludente de outras causas.

c) Direito comparado. Existem, como é evidente, precedentes estrangeiros também quanto a tal ponto. $O$ Código italiano e o Código português, a exemplo do que ocorre com os doentes mentais, criam 
dois tipos de medidas, a interdição e a inabilitação, conforme o grau da gravidade da incapacidade derivada da surdo-mudez ou da cegueira. A iécnica meramente exemplificativa tem seu antecedente no célebre § 1.910 do BGB que, após mencionar a invalidez física köperliche - Gebrechen - detém-se em casos - exemplo: os de surdez, cegueira ou mudez - insbesondere weil er taub, blind oder stumm ist.

d) Conclusão crítica. Ainda aí, quer-nos parecer que a emenda "foi pior do que o soneto". Muito melhor a rigidez do sistema atual quanto ao surdo-mudos, que admite casos de incapacidade absoluta total e de incapacidade absoluta parcial, mas não admite os casos de incapacidade relativa. A criação da incapacidade relativa para a surdo-mudez permite o surgimento dos problemas de cisão no tempo característicos da eficácia ex•nunc da interdição nesse tipo de incapacidade. Por outro lado, a transformação da surdo-mudez em causa meramente exemplificativa introduz a perplexidade e a insegurança no delicadíssimo campo das incapacidades absolutas. A que outra causas permanentes pretende referir-se 0 art. $4 .^{\circ}$, III? à cegueira? No que tange à surdo-mudez, 0 art. 1.978 do Anteprojeto, idêntico ao art. 451 do atual Código ganha, porém, em contexto novo, significado novo, podendo-se admitir que, no caso específico dos surdo-mudos, a delimitação do alcance da curatela prevista pelo referido dispositivo tenha o sentido de curatela limitada.

3.3.3. Incapacidade acidental. Também aqui há precedentes no Direito esirrangeiro. O recente Código luso, por exemplo, em seu art. 353 , permite a anulação de ato praticado por indivíduo capaz que "se encontrasse acidentalmente incapacitado de entender o sentido" da declaração ou não tivesse o livre exercício da sua vontade, contando que o fato fosse notiório ou conhecido do declaratário, entendendo-se por fato notório o que uma pessoa de normal diligência (o) teria podido notar". No Anteprojeto de Código Civil Brasileiro, o instituto surge como causa de anulabilidade do negócio jurídico. Art. 174 "Igualmente é anulável o negócio jurídico realizado por pessoa que, apesar de não interditada, estava, por qualquer causa, mesmo transitória, impossibilitada de entender de querer no momento em que ele foi celebrado". Admitindo-se que o dispositivo queira solucionar principalmente problemas como o da embriaguez passageira ou da ação de tóxico sobre pessoa não viciada, ganha clareza a mens do dispositivo; Se toxicômanos e ébrios contumazes só não incapazes após a interdição, torna-se possível anular, porém, o ato ou negócio celebrado em momento em que uma das partes estava sob a ação do álcool ou do tóxico, sem que tal pessoa seja um viciado, sendo, por conseguinte, ininterditável. Acontece, porém, que a expressão 
"mesmo transitória" empregada pelo art. 174 do Anfeprojeto, dá a entender que também as causas permanentes podem integrar o suporte fático da ıncidência da norma. O que significa uma inutilização da norma de segurança tradicional em nosso Direito e segundo a qual os atos praticados por pessoas relativamente incapazes (v.g., o caso dos pródigos) só serão anuláveis se, no momento do ato, já o incapaz estava interdirado pois, no caso dos relatıvamente incapazes, a interdição cria, constitui a incapacidade. Agora, pelo sistema do Anteprojeto, um ébrio ou toxicômano não interditado (e, por conseguinte, capaz de fato, pois que sua incapacidade só é criada pela interdição, eis que relativa) pode ter ato seu anulado se, a posteriori, for provado que, no momento do negócio ou ato, esłava por causa permanente, impossibilitado de querer ou entender. O que nos parece, dała venia, extremamente perigoso para a segurança da vida jurídica.

3.3.4.A ausência. A ausência deixa de ser causa de incapacidade, o que nos parece um evidente progresso lógico e científico, eis que a única semelhança entre o caso dos ausentes e o caso dos incapazes é a atuação de um curador, não se aplicando ao ausente, por óbvios motivos, as regras da nulidade ou anulabilidade de atos que pratique, onde esteja presente. Cria-se porém institutio novo, a morte presumida prevista pelo art. $8 .^{\circ}$ do Anteprojeto, para os casos de extrema probabilidade de morte de quem estava em perigo de vida (I) e para a hipótese de desaparecimento em campanha ou aprisionamento de uma pessoa não encontrada até dois anos após o término da guerra (II). Tais pessoas, após as necessárias averiguações, são declaradas judicialmente morłas, sem decretação de ausência. Assim, enquanto, pelo parágrafo único do art. 1.763, é mantida a regra do parágrafo único do art. 315 do vigente Código, que excluiu a ausência como causa de dissolução do vínculo matrimonial, cria-se instituto novo, o da morte presumida que, ao contrário da ausência, dissolve vínculo matrimonial. São evidentes os bons intuitos da Comissão. $O$ que não diminui o perigo de aplicações desonestas, principalmente do inciso I do art. $80^{\circ}$.

\subsection{Dos direiłos da personalidade}

3.4.1. Breve noção. Começa o capítulo dedicado pelo Anteprojeto aos "Direıtos da Personalidade", inovação, relativamente ao atual Código, que se fazia inadiável, com a proclamação do princípio geral intransmissibilidade e indisponibilidade (de que é aplicação a insuscetibilidade de auto-limitação de seu exercício) - art. 12 - "com exceção dos casos previstos em lei". O art. 13 consagra a dualidade de sanções que protegem a pessoa lesada em seus direitos de personalidade - a possibilidade de "exigir que cesse a ameaça, ou a lesão" 
e a sanção de perdas e danos, tudo isso "sem prejuízo de outras sanções previstas na lei". Nesse particular, muito superior é a redação do dispositivo correspondente do Código português, art. 70, 2 "Independentemente da responsabilidade civil a que haja lugar, a pessoa ameaçada ou ofendida pode requerer as providências adequadas às circunstâncias do caso, com o fim de evitar a consumação da ameaça ou atenuar os efeitos da ofensa já cometida". Regula-se o problema da proteção aos direitos da personalidade após a morte do respectivo titular. A redação (art. 13, parágrafo único - "Dar-se-á igual proieção ao morto...") é pouco feliz, dando a impressão de perdurar a personalidade após a morte. A legitimação ativa, em tal caso, é limitada pelo Anteprojeto ao conjuge sobrevivente, parentes da linha reta e colaterais até $\circ 4 .^{\circ}$ grau. Regulam-se a seguir, os atos de disposição do próprio corpo, destinados a produzir efeitos ainda em vida (inclusive os transplantes) e após a morte, arts. 14 e 15, o direito a recusa a tratamento médico ou cirúrgico, art. 16, a proteção ao nome e ao pseudônimo, arts. 17 a 20, bem como a proteção à imagem da pessoa, a seus escritos e sua palavra (art. 21).

3.4.2. Omissões. Assuntos importantes e que haviam merecido tratamento legal da parte do Anteprojeto ORLANDO GOMES foram esquecidos pelo novo Anteprojeio. Dentre tais assuntos, merecem menção o problema do direito a dispor sobre o destino do próprio cadáver, e o difícil problema das consequências da recusa a submeter-se a perícia médica.

3.4.3. Crítica. Fixado pelo art. 21 ○ princípio segundo o qual "a difusão de escritos, a transmissão da palavra, ou a publicação, a exposição ou a utilização da imagem de uma pessoa poderão ser proibıdas, a seu requerimento e sem prejuízo da indenização que couber, se lhe atingirem a honra, a boa fama, ou a respeitabilidade, ou se destinarem a fins comerciais", ○ Anteprojeto retira tal proteção se tais violações forem "autorizadas", ou se forem "necessárias à administração da justiça ou à manutenção da ordem pública". Essa segunda ressalva merece nossa mais absoluta repulsa, colocada nos termos em que o foi. É preciso levar-se em conta que vários são os direitos da personalidade que 0 art. 21 se destina a tutelar, e que tal tutela, envolve, além do direito à imagem, direito a inviolabilidade do sigilo de correspondência, e de escritos confidenciais, bem como o direito a impedir a utilização da própria voz, violação tornada possível e fácil com o progresso dos instrumentos de gravação. O Código vigente, que só menciona, dada a época em que foi escrito, o problema da proteção à palavra escrita, ocupa-se do assunto em seu art. 671, cujo capuł veda a publicação de manuscritos, sem licença do autor, sob pena de perdas e danos, e cujo parágrafo único proibe, sem a 
necessária permissão dos autores, publicação das cartas-missivas, salvo juntada como documentos em autos judiciais. $O$ próprio Código português, no que tange ao problema específico das cartas-missivas, divide-as em confidenciais e não-confidenciais e só permite a publicação das primeiras com o consentimento de seu autor ou o suprimento judicial de tal consentimento, pré-excluída a possibilidade de tal consentimento quando se pretenda utilizar as cartas como do. cumento literário, histórico ou biográfico. Apesar da provável influência que famoso episódio ligado a documentos íntimos do poeta FERNANDO PESSOA deve ter sido na redação do dispositivo do Código lusitano, ressalta, de logo, sua maior fidelidade às tradições jurídicodemocráticas de respeito à intimidade, ao sigilo, se comparado com - arr. 21 do Anteprojeto. Neste, admitindo-se que a palavra "autorizadas" se refira ao consentimento do autor dos escritos, titular da palavra, ou da imagem, a alternativa ou permite que escritos, palavra ou imagem, sem qualquer controle judicial, sejam divulgados desde que tal prática seja necessária à "administração da justiça ou à manutenção da ordem pública". Onde a exigência do controle judicial? O dispositivo nos parece policialista, toralitário, e até inconstitucional, em face do $\S 90^{\circ}$ do art. 153 da vigente Carta Constitucional.

\section{Das pessoas jurídicas}

4.1. Das pessoas jurídicas de Direito Público Interno. A enumeração apresenta atualizações, em comparação com o Código Civil, mantida a orientação no sentido de concentrar no Código Civil o elenco de tipos de pessoas jurídicas, o que nos parece correto, eis que a noção mesma de pessoa jurídica encontra, quanto ao aspecto legal, sedes materiae no Código Civil. São incluídos na enumeração os Territórios (art. 41, II) e as autarquias (art. 41, IV), omitidos - o que é uma falha - sindicatos e partidos políticos - embora, quanto aos prìmeiros, possa surgir a objeção a nossa crítica derivada da natureza controvertida de sua personalidade jurídica (Direito Público ou Privado?). No que nos concerne, porém, e dada a natureza uni-sindical do regime entre nós imperante, e aré mesmo a existência do imposto Sindical, não temos dúvidas em considerar os sindicatos, de lege lata, como pessoas jurídicas de Direito Público. $O$ inciso $V$ considera de Direito Público "as demais entidades de caráter público criadas por lei". Um enigmático parágrafo único, do mesmo art. 41, considera como devendo reger-se, "no que couber", quanto ao seu funcionamento, pelas normas do Código Civil, "as pessoas jurídicas de direito público, a que se tenha dado estrutura de direito privado". A que se está a referir tal dispositivo? Quererá prever fundações de Direito Público, dando assim razão aos que pretendem já existir em tais pes- 
soas jurídicas em nosso Direito? (De nossa parte, somos dos que entendem, de lege lała, só existirem entre nós as fundações como pessoas jurídicas de Direito Privado). Mas, nesse caso, estará sendo ilusória a aparente definição do art. 43, III, pelo caráter privatístico das fundações. Quererá o Anteprojeto referir-se às empresas públicas? De qualquer forma, o dispositivo é nebuloso, e esse defeito avulta, se considerarmos que, em vários outros pontos, aparecerem no Anteprojeto referências às tais pessoas jurídicas de Direito Público a que tenha sido dada estrutura de Direito Privado (v.g., art. 98, parágrafo único, dentre outros).

4.2. Das pessoas jurídicas de Direito Privado. Merece, a nosso ver, os maiores louvores, a nítida separação introduzida entre associações (os collegia, as universitates do Direito Romano) e as sociedades (societałes, em Roma). A distinção, muito clara, no Direito Francêes, no Direito Alemão, codificados em data anterior à do nosso Código, foi lamentavelmente descurada pelo diploma de 1916. E possível até que a intenção dos autores de nosso Código tenha sido a de evitar as polêmicas que, por exemplo em França ou na Bélgica, puseram em dúvida a personalidade jurídica das sociedades. $O$ que não justifica, embora explique, o descuido que teve o Código em traçar as fronteiras entre os dois grandes tipos de entidades representativas de grupos de seres humanos. O Anteprojeto sana essa falha, regulando as associaações na Parte Geral (art. 52-60) e as Sociedades no Livro II ("Da Atividade Negocial"). O princípio da igualdade de direitos entre associados (art. 54), somado a essa clara distinção, deverá ter o condão de acabar com a figura teratológica e híbrida, que se está tornando comum no Brasil, do clube cujos associados dispõem, por norma estatutária, de tantos votos quantas as ações, e que admite até pessoa jurídica como associado de clube, o que nos parece incompatível com a natureza de uma associação. Muito haveria a dizer sobre o regramento editado relativamente às sociedades, porém, dada a taxinomia adotada pelo Anteprojeto, a matéria foge ao âmbito deste trabalho. Ressalte-se ainda a preocupação que teve o Anteprojeto de oferecer um corpo mínimo de regras relativamente às associações, conteúdo mínimo dos Estatutos, matérias em que nosso Código é totalmente omisso. Em matéria de fundações, existe impropriedade ("componentes") no art. 66, I, devida a provável erro de imprensa, onde deveria estar escrito "competentes".

4.3. Das sociedades irregulares. No Código vigente, art. 20, $\S 2 .^{\circ}$, dispositivo existe que permite sejam elas tidas por pessoas jurídicas de capacidade de Direito restringida. A esse respeito, escrevemos trabalho em que procuramos demonstrar a total inanidade dos esforços dos que, reconhecendo embora titularidade de direitos - 
por exemplo, para defesa em juizo - à sociedade não registrada, teimam em negar-lhe a personalidade, com capacidade de gozo restringida ("Personalidade jurídica da sociedade irregular", in Revista Jurídica, Porto Alegre, vol. 76, pág. 5-26). Os autores do Anteprojeto optam, porém, pela tese negadora da personalidade jurídica das sociedades irregulares, através da supressão de dispositivo que equivalesse ao atual $\S 2 .^{\circ}$ do art. 20 , e da edição do inequívoco art. 1.049, que considera os bens e dívidas sociais da sociedade não registrada "patrimônio especial, de que os sócios são titulares em comum". A solução, embora frequentemente alvitrada por juristas, parece-me artificial, eis que a diferença entre a sociedade e a comunhão, antes de ser jurídica, é ontológica, radica no próprio ser, derivando do caráter estático, de mero gozo em comum de direitos, próprio da comunhão, e dinâmico, dominado pela idéia de obra a realizar HAURIOU), típico da instituição personalizável. O regisiro, mera nota acidental, nada acrescenta ao ser da entidade. Trata-se de terreno em que o legislador deve guardar fidelidade à realidade, à vida, guardando-se de personalizar o impersonalizável (a comunhão, por exemplo) e de negar personalidade àquilo que, ontologicamente, tem características de pessoa, sob pena de cair nos artifícios de que a vida se vinga por meios de artis em que é fértil a prática dos homens, como lembrou SALEILLES em seu célebre trabalho.

4.4. O combate ao abuso. $O$ art. 49, na esteira da experiência fornecida pelo Direito Comparado, procurou coibir a chamada "fraude por meio da pessoa jurídica", ou "abuso da personalidade jurídica". Bem teria andado se se tivesse a Comissão limitado à norma do parágrafo único, que, sem prejuízo de outras sanções cabíveis, manda responder, em tais casos, pelas dívidas, "conjuntamente com os da pessoa jurídica, os bens pessoais do administrador ou representante que dela se houver utilizado de maneira fraudulenta ou abusiva, salvo se norma especial determinar a responsabilidade solidária de todos os membros da administração". Até aí, tudo muito bem. O que não se concebe, porém, é que, para se sanar a lesão de que a pessoa jurídica foi vítima, pois seu nome foi utilizado, em proveito próprio, por sócios ou administradores desonestos, seja a pessoa jurídica dissolvida. Se é isso, nada mais, nada menos, que é autorizado pelo capuł do mencionado art. 49, que permite a dissolução da pessoa jurídica de que se abusou, a requerimento do lesado ou do Ministério Público, e por decisão judicial. Cura-se a doença cortando-se a cabeça ao doente. Acode-se ao lesado tirando-se-lhe a vida. Urge retirar ao Anteprojeto - perigoso radicalismo dessa sanção de dissolução.

(2) Raymond Saleilles, "Dé la Personnalité Juridique", Paris, 1922, ed. da "Librairie Arthur Rousseau", pág. 16. 
4.5. Os direitos da personalidade. Atendendo aos reclamos da Doutrina mais moderna, o art. 51 aplica às pessoas jurídicas, no que couber, a proteção dos direitos da personalidade".

\section{Dos Bens}

5.1. Das diferentes classes de bens. Esse Livro da Parte Geral representa sensível melhoramento, relativamente ao Código vigente. Não temos, no particular, críticas a fazer nem sugesiões a formular; tão só louvores a expressar. Em fórmula lapidar (art. 78) foram considerados bens imóveis "o solo e tudo quanto se the incorporar natural ou artificialmente", excluída a discutida e perigosa categoria dos imóveis por acessão intelectual e, por conseguinte, excluídos do Anteprojeto dispositivos que equivalessem aos atuais 43 , III e 45 . Como bens móveis foram expressamente incluídas "as energỉas naîurais que tenham valor econômico" $(82,1)$, sanada, assim, lacuna do nosso Código que o diploma penal de 1940 já em parte procurara preencher, porém tão só para efeitos penais (furto de energia). Omitiu-se 0 artificial dispositivo do art. 44, 1 do Código vibente, que considera imóveis "para os efeitos legais" as apólices da dívida pública oneradas com cláusula de inalienabilidade. Adequadas e técnicas definições delinearam as universalidades, de fato e de direito (arts. 89 e 90), as pertenças (arts. 92 e 93). No disciplinamento dos bens públicos, introduziu-se princípio novo, que nos parece, em princípio, salutar, e que modifica, radicalmente, nosso Direito: a usucapilidade dos bens públicos dominicais (art. 101). Anotariamos apenas uma omissão - a conceituação, que nos parece indispensável, de partes integrantes, essenciais e não essenciais.

5.2. Do Bem de Família. Por necessidade de cotejo com o Código vigente, dele tratamos aqui. O Anteprojeto, porém, regulou-o no Livro dedicado ao Direito de Família, e o fez dentro de espírito que representa visível esforço de viabilização do instituto. Na esteira do Direito italiano, admitiu-se tenha o bem de família por objeto ou "prédio residencial ou rural" (art. 1.924) ou parte do patrimônio do instituidor, parte que não poderá ultrapassar nenhum dos dois tetos estabelecidos pelo Anteprojeto, o teto relativo - um terço do patrimônio líquido existente ao tempo da instiłuição - e o teto absoluto - seiscentas vezes o maior salário mínimo vigente do País. (art. 1.923). O art. 1.931 regula a extinção ou subrogação real, ouvidos o instituidor e o Ministério Público, em caso de impossibilidade de manutenção. E o art. 1.933, preceituando a não extinção do bem de família em consequência da dissolução da sociedade conjugal, prorroga-lhe a existência. Tal prorrogação poderia, porém, ter tido a 
previsão de seu termo normal - a maioridade do filho mais jovem do casal - assunto em que se omitiu o Anteprojeto.

\section{Dos Fałos Jurídicos}

6.1. Da classificação. O Anteprojeto regula, de modo expresso, os negócios jurídicos (quase todo o livro destinado aos fatos jurídicos tem os negócios jurídicos por objeto), os atos jurídıcos lícitos (aos quais reserva apenas um art., o de n. 186 - "Aos atos jurídicos lícitos, que não sejam negócios jurídicos, aplicam-se, no que couber, as disposições do Título anterior" ${ }^{\prime \prime}$ ), e os atos ilícitos. Nada se diz nem dos fatos em sentido esiritito, nem dos atos-fatos, mas já há, evidentemente, um progresso técnico. Suprime-se o capítulo do atual Código que vai do art. 74 ao art. 80, o que é um progresso, pois tal capítulo sempre foí digno de crítica pela péssima localização, e, ademaìs, consagra uma doutrina do direito de ação superada pela moderna ciência processual, além de conter princípios estranhos ao Direito Material.

6.2. Generalidades. Introduz o Anteprojeto um princípio geral de interpretação dos negócios jurídicos, o do art. 112, destinado a valorizar a boa fé e os usos do lugar da celebração. Surge em nosso Direito, através do art. 109, o instituto da reserva mental (relevante quando dela tivesse conhecimento o destinatário da declaração de vontade). O princípio do atual art. 83 é modificado na forma constante do art. 104. "A incapacidade relativa de uma das partes não pode ser invocada... "A contrario sensu, é consagrada a tese da oponibilidade da incapacidade absoluta. Outra alteração no mesmo princípio: a incapacidade relativa de uma das partes, além de não poder ser invocada pela outra em benefício próprio, também não aproveita aos co-interessados capazes, "salvo se, neste caso, for indivisível o objet'o do direito ou da obrigação comum". A introdução da restritiva "neste caso" tornou mais técnico o regramento, pois foi feita a necessária distinção entre as vantagens que, da incapacidade, pretende extrair a "outra parte" do Negócio Jurídico e as vantagens visadas por outras pessoas cujos interesses estejam, ao contrário, situados, do mesmo "lado" do negócio que os da parte incapaz, só neste caso sendo lógico falar-se em direito ou obrigação "comum".

6.3. Condição, termo e encargo. O Código vigente, em seu art. 116, considera inexistentes as condições fisicamente impossíveis e as de não fazer coisa impossível. Ao contrário, as juridicamente impossíveis (e, de modo implícito, as ilícitas) invalidam os atos a elas subordınados. O Anteprojeto modifica tal sistema de modo radical. Através de seu art. 123, distingue as condições contraditórias ou in- 
compreensíveis (também chamadas perplexas por parte da Doutrìna), as ilícitas ou de fazer coisa ilícita e as impossíveis, físicas ou juridicamente. As contraditórias e as ilícitas viciam de invalidade o negócio jurídico que lhes seja subordinado. As impossíveis são objeto de distinção. Seja a impossibilidade física ou jurídica, se suspensiva a condição (art. 123, I), a consequência é ainda a invalidade do negócio jurídico. Se resolutiva, tem-se por inexistente (art. 124), Também se tem por inexistente a condição de não fazer coisa impossível (art. 124). A solução é semelhante à constante do art. 271 do Código português. Atende aos reclamos da Doutrina, que censura em CLOVIS a ausência da necessária distinção entre as categorias do ilícito e do impossível juridicamente (v. g., PONTES DE MIRANDA, "Tratado de Direito Privado, Borsoi, ed. 1970, vol. 5 §543, 4, pág. 128: "condição ilícita, que CLOVIS BEVILAQUA... confundia com as juridicamente impossíveis, por desconhecer a diferença entre o limitativo e o reprovativo, o ilegal e o ilícito"). Faltou, porém, a necessária coordenação com a parte do Anteprojeto relativa ao Direito das sucessões, a não ser que tenha sido expressa intenção fazer a regra dos arts. 123, 124 incidir também em matéria testamentária. Tudo indica, porém, que essa não tenha sido a intenção da Comissão, como a seguir será demonstrado. Com efeito, a regra, que vem dos sabinianos, e que a tradição trouxe de Roma, é a não-incidência da regra sobre invalidade dos negócios jurídicos subordinados a condição ilícita ou a condição juridicamente impossível em matéria de negócios mortis-causa $O$ recente Código Português consagra essa tradicional distinção, em seu art. 233, 2, ao considerar não-escrita a condição testamentária "contrária à lei ou à ordem pública, ou ofensiva dos bons costumes... ainda que o tesłador haja declarado o contrário". É que, nos testamentos, ao contrário do que ocorre nos negócios inter vivos é a vontade de uma pessoa, o testador, tornada definitiva e irrevogável pela morte, a regra suprema de interpretação. Ressalva o Código luso uma exceção - a do art. 2.186, que nulifica a disposição iestamentária quando "da interpretação do testamento resulte que foi essencialmente determinada por um fim contrário à lei ou à ordem pública, ou ofensivo dos bons costumes", hipótese em que a própria vontade do testador estava dirigida para meta ilícita ou imoral. Se fosse intenção da Comissão estender a regra da invalidade dos negócios jurídicos subordinados a condição ilícita aos negócios mortis-causa, não se justificaria a regra inserta no art. 2.109, VI, em que se considera nula a disposição testamentária "quando resultar, exclusivamente, da razão invocada pelo testador, e se provar ter ele... sido movido por motivo ilícito". A admitir-se que a extensão do princípio da nulidade do negócio aos testamentos (regra proculeiana) tenha sido a intenção 
da Comissão, ter-se-ia o seguinte absurdo: para o caso menos grave (condição ilícita ou juridicamente impossível suspensiva) - negócio nulo, sanção mais grave; para o caso mais grave (vontade do testador direfamente movida por motivo ilícito), só a cláusula nula, sanção menos grave. Supriu-se omissão do Código quanto aos encargos. llícitos ou impossíveis, serão considerados não-escritos. salvo quando constituam o motivo determinante da liberalıdade, caso em que invalidarão o negócio jurídico (art. 137).

\subsection{Dos defeitos do negócio jurídico.}

\subsubsection{Do erro.}

\subsubsection{Delimitação do erro substancial. 0 problema da cog-} noscibilidade. Havia um assunto, em matéria de erro, em que se fazia capital uma definição - o problema da opção entre o direito do que errou à anulação e o respeilo à boa fé da outra parte. No caso do dolo, é justo que o seu agente, que induziu em erro a outra parte, sofra com as consequências, que the sejam prejudiciais, da anulação do negócio; não assim, porém, no caso do erro, em que, sem que nenhuma conduta censurável pudesse ser imputada à outra parte, que crerá estar a celebrar negócio extreme de vícios, pode ela vir a sofrer prejuizo, em consequência da anulação. O Direito Italiano (Cod. Civ. It., art. 1.428) resolveu o problema considerando pressuposto de anulabilidade a possibilidade de reconhecimento do erro (portanto, a cognoscibilidade, conhecimento presumível) pelo outro participe do negócio jurídico, eis que, em tal caso, pelo menos imprudência ou negligência é imputável à pessoa que virá a ser prejudicada com a anulação. O mesmo critério, em sua linhas essenciais, foi o adotado pelo Código Português que, em seu art. 247, introduziu o critério do conhecimento real ou presumido - a declaração negocial "é anulável, desde que o declaratário conhecesse ou não devesse ignorar a essencialidade, para o declarante, do elemento sobre que incidiu, - erro". O BGB adotou critério diametralmente oposto - o ato é anulado dando-se ao prejudicado, porém, pretensão para a cobrança de indenização pelo chamado "interesse negativo". O Anteprojeto brasileiro adotou nitidamente o sistema italiano, sendo elemento do erro capaz de gerar anulação a cognoscibilidade pela outra parte. Para a conceituação dessa cognoscibilidade, ainda na esfera do diploma peninsular, art. 1.431, adotou o Anteprojeto (art. 138, parágrafo único) o critério abstrato-erro substancial é o que "poderia ser percebido por pessoa de diligência normal em face das circunstâncias do negócio". A introdução dessa noção de conhecimento presumıdo, de cognoscibilidade, traria fatalmente, como trouxe, o elemento padrão abstrato, o vir medius. Esse critério traz consigo toda a gama de 
artificialismo própria dos padrões abstratos e, no fundo, estabelece contradição com o critério concreto de mensuração da coação consagrado pelo Código Civil, art. 99, e mantido pelo Anteprojeto, art. 152. Em nosso entender, teria sido preferível não incluir o requisito da cognoscibilidade como elemento conceitual do erro substancial, permitir a anulação do negócio jurídico, independentemente de tal requisito, e reconhecer ao prejudicado com o erro a pretensão a indenização. O ônus da prova da ignorância do vício da outra parte seria da parte que pleiteasse a indenização, e o juiz, ao apreciar a prova, levaria em con'a as condições concretas da parte, e não padrões abstratos, axiomaticamente falsos.

6.4.1.2. Erro de direitc. Introduz-se, de modo expresso, o erro de direito como possível fundamento de anulação. $O$ negócio é anulável por erro "quando, sendo de direito e não implicando recusa à aplicação da lei, for o móvel único ou principal do negócio jurídico" (art. 137, III). A inclusão do erro de direito é progresso relevante, não nos parecendo, todavia, feliz a admissão de erro de direito tão só quanto não haja "recusa à aplicação da lei". Se houver recusa à aplicação da lei, não haverá erro de espécie alguma, mas fraude à lei, havendo por isso mesmo imprecisão terminológica em admitir-se, a contrario sensu, erro de direito irrelevante na recusa à aplicação da lei. Por outro lado, teria sido elogiável a inclusão, que fora feita pelo Anteprojeto HAROLDO VALLADÃO de "lei geral de aplicação das normas jurídicas" de padrões concretos destinados a permittir a real avaliação da existência do erro e que funcionariam ao mesmo tempo como pressupostos de existência do erro a residência em locais afastados dos grandes centros, a extrema ignorância ou incultura. E sempre através da referência ao concreto que se faz o Direito chegar mais rente à Vida.

4.1.3. Erro quanto ao motivo - A "falsa causa" a que se refere o art. 90 do Código é corrigida para "falso motivo". Não partilhamos da opiinão dos que criticam a alieração, constante do art. 140 do Anteprojeto, considerando-a pelo contrário, altamente benéfica, pois só como referência ao falso motivo pode ser entendida a disposição do atual art. 90, se não se quiser fugir ao conceito objetivo e genérico, tipificador, que tem a causa na moderna Doutrina.

4.2. Do dolo. Em matéria de dolo, só duas alterações foram feitas - permitiu-se a anulação do negócio jurídico por dolo de terceiro, não apenas em caso de conhecimento efetivo do dolo por uma das partes, como no atual art. 95, mas também em caso de conhecimento". (art. 148). Sempre a presença dessa noção artificial de conhecimento presumido, de cognoscibilidade. Por trás, subjacente, aqui de 
modo implícito, a mesma noção do vir medius, axiomaticamente falsa necessária à composição da noção abstrata de cognoscibilidade. Regulou-se, o que foi bom, ainda no mesmo art. 148, o caso em que o dolo de terceiro não conduza à anulabilidade - o terceiro responde por perdas e danos. O art. 149 regulou o problema do dolo do representanie, distinguindo, de modo feliz, entre a hipótese do representante legal (seu dolo só obriga o representado a responder civilmente até a importância do proveito que teve, na forma do art. 96) e a do representante convencional, escolhido pela parte, e que por isso mesmo acarreta ao representado a responsabilidade solidária, com o representante, pelas perdas e danos.

\subsection{Da coação.}

4.3.1. Pressupostos. Duas alterações de monta, nos pressupostos por lei exigidos para que a coação se torne vício capaz de aular o negócio jurídico, foram introduzidas pelo art. 151 do Anteprojeto, correspondente, na função, ao art. 98 do Código. Não se exigiu mais a mensuração absurda de danos exigida pelo final do art. 98, e que a jurisprudência vinha dispensando. Ou seja -o temor de danos à pessoa, família, ou bens do coacto não terá de ter por objeto dano "igual, pelo menos, receável do ato extorquido". Exigir-se-á, agora, apenas, que o dano temido, além de iminente, seja considerável. Salutar a alteração, em que deve ter exercido provável influência o prof. SILVIO RODRIGUES, que defende esse ponto de vista em seu conhecido trabalho monográfico sobre a coação. Como deve provável inspiração ao mesmo eminente especialista o parágrafo único do mesmo art. 151, o qual, quando a pessoa a que diga respeita o dano temido não integre a família do coacto, autoriza o juiz a, com base nas circunstâncias, decidir se houve coação. A disposição tem origem no art. 1.436 do Código Italiano.

6.4.3.2. Da coação exercida por terceiro. $O$ art. 154 começa, em seu caput, por editar regra identica à do caput do art. 101 do Código - "A coação vicia o ato, ainda quando exercida por terceiro". A partir daí, porém, é totalmente distinto o regramento do Anteprojeto. Pelo Código vigente, a coação exercida por terceiro vicia sempre $\circ$ ato, sendo irrelevante para tal o discutir-se se a coação foi ou não previamente conhecida da parte a quem aproveite. Esse problema surge para o efeito da responsabilidade por perdas e danos. Se a parte a quem aproveite a coação conheceu-a previamente, responde solidariamente com o coacto pelas perdas e danos $\left(\S 1 .^{\circ}\right)$; se não conhecia, só o coacto responde $\left(\S 2 .^{\circ}\right)$, pois que, evidentemente, "a parte prejudicada com a anulação do ato" a que se refere o $\S 2 .^{\circ}$ é a mesma parte favorecida pela coação. O Anteprojeto alterou as 
regras. Na verdade, é o que se pode deduzir da interpretação a contrario sensu do $\S 1 .^{\circ}$ do art. 154, a coação só vicia o ało, tornando-o anulável, quando previamente conhecida da parte a quem aproveite. Quando não conhecida de modo prévio, "o negócio jurídico subsiste, mas o autor da coação responderá por todas as perdas c danos do coacto". Em face disso, resulta totalmente absurdo e despido de sentido o $\S 2 .^{\circ}$ do art. 154 , mera reprodução do $\S 2 .^{\circ}$ do a.t. 98, do Código que, no sistema deste, ganhava sentido e força mas, no sistema do Anteprojeto, é corpo estranho inadmissível. A "parte prejudicada com a anulação do ało" só pode ser favorecida com a coação. Se ela não soube da coação, o negócio subsiste, não há anulação. De modo que o $§ 2 .^{\circ}$ do Anteprojeto ("Se a parte prejudicada com a anulação do ato não soube da coação exercida por terceiro, só este responderá por perdas e danos") só pode ter resultado cle perdoável cochilo da Comissão Revisora, necessitado de urgente reparo.

6.4.4. Da simulação. Mantém-se o mau critério enumerativo do art. 102 do Código. $O$ que é mau, quando seria tão simples conceituar, por exemplo, na esteira da magnífica definição legal que pode ser extraída do art. 240, 1 do Código português - divergência entre a vontade real do declarante e a declaração negocial, causada por acordo entre declarante e declaratário, no intuito de enganar terceiros. De modo estranho e represeniativo, a nosso ver, de grave omissão, deixou-se de consagrar a distinção entre simulação maliciosa e a inocente, objeto do art. 103 do atual Código. Alterou-se de modo fundamental a regra sobre legitimidade ativa para a propositura da ação de anulação por simulação, admitindo-se a demanda de anulação por proposta dos próprios contraentes, ressalvados os direitos de terceiros de boa fé. A alteração, contida no art. 156, parece-nos perigosa. Finalmente, foi introduzida preciosa regra, a do art. 157, que consagra expressamente, para a simulação relativa, o princípio da conversão ou da extraversão, como outros preferem, mandando-se subsistir o negócio jurídico dissimulado "se válido for na substância e na forma".

6.4.5. Da fraude contra credores. Ampliou-se a legitimidade ativa da ação pauliana, admitindo-se sua propositura não apenas pelos credores quirografários como por aqueles "cuja garantia se tornar insuficiente" (art. 160, § 1. ${ }^{\circ}$ ). Elogiável alieração. Como também digna de louvor inteligente medida prática introduzida pelo parágrafo único do art. 162, que permite ao adquirente dos bens em fraude, quando os tenha adquirido por preço inferior ao real, e deseje conservar - domínio dos bens, depositar o preço que corresponda a seu valor real. Perdeu-se, porém, na redação do Anteprojeto, preciosa oportu- 
nidade, deixando-se de alterar a consequência da fraude. O Anteprojeto ainda trata a fraude como um vício, acarrelador, portanto, de anulabilidade, quando, no melhor entendimento, o caso seria de ineficácia, em sentıdo estrito.

\subsubsection{Da lesão e do estado de perigo}

\subsubsection{Da lesão}

a) Os anrecedentes de Direito Comparado. A lesão surge no Anteprojeto através do art. 159. São conhecidos os lineamentos essenciais às três grandes versões dó instifuto da lesão no Direito Comparado. No sistema francês, não existe norma geral sobre o assunto, mas regras específicas a determinados negócios jurídicos, em especial à compra e venda de imóveis e à partilha na sucessão hereditária. O vício é de desproporção de valores, apurado de acordo com tarifamento em lei previsto (na compra e venda, há lesão se o vendedor foi lesado em mais de 7/12 do preço de um imóvel; na partilha, basta 1/4), dispensa-se qualquer elemento subjetivo, a ação é de rescisão, sendo parte legítima para propô-la a vendedor do imóvel ou o herdeiro prejudicado, podendo o réu impedir a rescisão com o oferecimento da diferença de preço. No sistema alemão, há normas geral (BGB, § 138) o critério da desproporção é judicial e não tarifado (o juiz é que dirá se houve ou não vantagens para uma das partes em chocante desproporção - in auffäligen Missverhältnisse - com as auferidas pela outra parte), há um elemento subjetivo necessário à configuração da lesão (o dolo de aproveitamento - uma das partes explorou a necessidade, leviandade ou inexperiência da outra) e a consequência é a nulidade absoluta. No sistema italiano, são exigidos os elementos exigidos pelo sistema alemão (desproporção e dolo de aproveitamento, definido como o aproveitamento do estado de necessidade da outra parte), tarifa-se a desproporção (de acordo com a tradição romana da laesio ultra dimidium, só há lesão juridicamente relevante quando excede à metade do valor real da prestação) e a consequência é também a ação de rescisão, que pode ser neutralizada pelo réu que ofereça modificação capaz de restaurar a equidade. A norma é genérica, arts. 1.448-1.450. O Direito Português, através do recente Código, art'. 282 e seguinte, ficou com a fórmula italiana, embora seja de inspiração germânica a conceituação das bases do instituto. Para maior aprofundametno do problema, nosso trabalho "Noticia sobre a Parte Geral do novo Código Civil Português, in Revïsta dos Tribunais $n .^{\circ} 431$, pág. 13 e seguinte, item 7 , letra $i$, págs. 31-33. Sendo a lesão caralogada como vício, a ação é de anulação no Código luso. 
b) Anteprojeto. Enquanto que o Projeto de Código de Obrigações de 1965, oriundo do Anieprojeto do prof. CAIO MARIO DA SILVA PEREIRA, arts. 64-65 e 77/79, seguia em suas linhas básicas o sistema italiano, embora nítida a influência alemã na conceituação dos pressupostos, especialmente quanto ao elemento subjetivo, o Anteprojeto atual seguiu diversa inspiração. Como no Projeto de 1965, o caso é de vício, gerador de anulabilidade. Mas, na conceituação do elemento subjetivo, a Comissão reproduziu (art. 159, caput) quase integralmenie 0 texto do art. 31 do Anteprojeto dos Ministros ORO. ZIMBO NONATO, PHILADELPHO AZEVEDO e HANNEMANN GUIMA RÃES, de 1941. Como naquele notável anteprojeto, o prisma da con-ceituação é outro. Não se olha o dolo de quem tenha procurado explorar a necessidade ou inexperiência alheia mas a circunstância de haver alguém emitido sua declaração de vontade "sob premência de necessidade, ou por inexperiência".

Inclusive, os §§ do art. 159, embora com a numeração invertida, correspondem aos parágrafos do art. 31 do Anteprojeto de 1941, apreciando-se a desproporção das prestações segundo os valores vigentes à época da celebração e excluindo-se a anulação se for oferecido "suplemento suficiente, ou se a parte favorecida concordar com a redução do proveiro". Esse retorno à inspiração de 1941 representa profunda reviravolta. Não se olha, como no sistema alemão e no sistema iłaliano, a atitude maliciosa do favorecido para sancioná-la mas, no fundo, como no sistema francês, a preocupação fundamental é acudir o lesado. Por um lado sana-se o vício de incoerência que macula os sistemas italiano e porługuês que, sem a coragem de levar até as últimas o prisma-punitivo, sancionador, dão meia volta na hora das consequências e optam pela anulabilidade, evitável pela volta à equidade, com o consentimento do Réu. O Código alemão tivera a coragem da coerência e da opção pela nulidade absoluta. O Anteprojeto de 1941 e o Anteprojeto atual, desejando chegar à anulabilidade, à sanabilidade do vício, tiveram o cuidado do estabelecimento de premissas coerentes. O ângulo é outro o estado psicológico do estado da vítima a proteger; não o estado psicológico do aproveitador a censurar. Porém, isso é verdade, é bom não esquecer que o. Anieprojeto de 1941 considerava a lesão como mera ampliação do conceito de coação, o que é expressamente reconhecido pelo ministro HAHNEMANN GUIMARÃES - a quem tributo a homenagem que the devo, eis que fui seu aluno de Direito Civil na então Faculdade Nacional de Direito - no "Estudo Comparativo" agora, e de modo oportuno, reeditado pelo Senado Federal, pag. 426. No contexto do Anteprojeto novo, não existe essa ampliação da noção de coação, a lesão é vício de lineamentos autônomos. 
6.4.6.2 . . Do eșiado de perigo. Conceituado pelo art. 158 como a situação em que alguém, "premido da necessidade de salvar-se, ou a pessoa de sua família, de grave dano conhecido pela outra parte, assume obrigação excessivamente onerosa". Fonte mediata é o art. 1.447 do Código Italiano, acolhida a redação dada pelo Projeto de 1965, art. 66. Estamos diante de instituto que guarda relação estreita com a coação, embora seu conceito dispenșe qualquer ato posirivivo de ameaça. Inclusive a edição de regra identica à do parágrafo único do art. 158 ("Tratando-se de pessoa não pertencente à família do declarante, o juiz decidirá segundo as circunstâncias") sublinha esse íntimo parentesco, pelo paralelismo com o art. 151, parágrafo único.

6.4.7. Omissões. Entendemos digna de menção as categorias do denominado erro obstáculo e da coação absoluta (vis absoluła), que conviria incluir no diploma civil, exatamente para extremá-la dos casos de vícios que simplesmenie tornem anulável o ato ou negócio jurídico. Já há antecedentes legislativos no Direito estrangeiro, sendo particularmente dignos de menção o art. 246 do Código Civil Português embora, a nosso ver, a consequência deva ser, em tais casos, a inexistência do negócio.

\subsection{Sistema de nulidade.}

6.5.1. Casos de nulidade absoluła. Estão enumerados no art. i68. Em relação ao atual art. 145, duas novidades - a nulidade por indeterminação de obịeto - art. 168, II e a nulidade por ilicitude do motivo determinante, comum a ambas as partes - art. 168, ill. Esta última modificação guarda coerência com a margem para investigação de motivos aberta no Anteprojeto. Outra novidade é a nulidade por ter o negósio jurídico a finalidade de fraude à lei, art. 169 .

6.5.2. Conversão do nulo. No plano das consequências da nulidade, a grande alteração é a consagração do princípio da possibilidade de conversão do nulo, na esteira do $\S 140$ do BGB e do art. 293 do Código Português. O negócio nulo pode ser "convertido" em um outro válido, do qual contenha os requisitos, quando o fim, "a que visavam as partes, permitir supor que o teriam querido, se houvessem previsto a nulidade". A inovação é salutar.

6.5.3. Casos de anulabilidade. Além da ampliação resultante do aumento de tipos de vícios do negócio jurídico, foram criados vários casos de anulabilidade que, a nosso ver erradamente, não foram concentrados na enumeração do art. 173. Na própria Parte Geral, inúmeros outros casos de anulabilidade existem. O caso do negócio consigo mesmo (art. 116). O caso do negócio concluído pelo repre- 
sentante, em conflito de interesses com o representado (art. 119) quando tal fato "era ou devia ser do conhecimento de quem com aquele tratou". Mais um vez, a introdução do conceito do conhecimento presumido tem por consequência problema de insegurança na vida jurídica, mormente em matéria de validade de ato jurídico. Por outro lado, a anulabilidade por incapacidade acidental prevista no art. 174 acarreta perplexidade cujas premissas já estão assentadas em item anterior do presente trabalho. Se a referida incapacidade é definida como impossibilidade de entender ou querer o ato no momento em que foi celebrado, e se isso se deve "a qualquer causa, mesmo transitória", uma causa permanente de entender e querer não será causa de nulidade, antes que de anulabilidade? Urge restringir a incidência do art. 174 tão só aos casos de causas transitórias.

6.6. Prescrição e Decadência. Merece elogios a triagem feita entre prazos prescricionais e decadenciais, de modo paciente e minucioso. Também merece elogios a decretabilidade ex-offício da prescrição, em favor de absolutamente incapaz, art. 193.

6.7. Da prova. As novidades nesse particular, inclusive quanto às provas fonográficas, cinematográficas, por meio de reprodução mecânica, em geral, (art. 222) estão corretamente equacionadas, inexistindo, a nosso ver, os defeiltos que outros críticos apontaram. 